\title{
Kakapo habitat selection on Hauturu-o-toi in relation to plant phenology
}

\author{
Zoë L. Stone ${ }^{1,3 *}$, Bruce Burns ${ }^{1}$, Ron Moorhouse ${ }^{2}$ and Mick N. Clout ${ }^{1}$ \\ ${ }^{1}$ Centre for Biodiversity and Biosecurity, School of Biological Sciences, University of Auckland, Private Bag 92019, Auckland, \\ New Zealand \\ ${ }^{2}$ Ecoscience Consulting Services, 653 Wairoa Gorge Rd, Brightwater, Tasman 7091, New Zealand \\ ${ }^{3}$ Present address: Level 3 Steele Building, The University of Queensland, Brisbane, Queensland 4072, Australia \\ *Author for correspondence (Email: z.stone@uq.edu.au)
}

Published online: 7 June 2017

\begin{abstract}
Kakapo (Strigops habroptilus) breed only when certain gymnosperm species produce unusually abundant mast seed crops, events that can occur up to 5 years apart. Kakapo were first translocated to the offshore island refuge of Hauturu-o-toi (Little Barrier Island) in 1982. Despite the absence of known breeding triggers, several breeding attempts did occur prior to the birds' removal in 1999. Although kakapo were reintroduced to Hauturu in 2012, the question of what triggers them to breed there remains a mystery. This paper re-examines unanalysed datasets to explore the link between kakapo habitat selection and plant phenology patterns on Hauturu during the 1990s. By comparing plant phenology with breeding attempts, we provide insights into potential breeding triggers, and the potential future of Hauturu as a sustainable refuge. We also provide an account of plant phenology patterns occurring on Hauturu. Resource selection ratios were calculated to determine habitat selection preferences using kakapo location data and a vegetation map of Hauturu. Analysis of plant phenology within preferred habitats was then undertaken to determine potential breeding triggers using a dataset of over 70 plant species collected from 1991-1995. Female kakapo that attempted to breed on Hauturu preferred Agathis australis (kauri) dominated vegetation to any other vegetation type. Phenology patterns coincided with kakapo breeding attempts, and attempted breeding years on Hauturu were years with high $A$. australis female cone abundance. The association between $A$. australis and breeding suggests that $A$. australis cone production could trigger kakapo breeding on Hauturu. With an increasing kakapo population and a limited number of suitable refuges, understanding the potential reproductive productivity of kakapo on Hauturu will be vital for their future management and recovery.
\end{abstract}

Keywords: breeding; kauri; Little Barrier Island; masting; Strigops habroptilus

\section{Introduction}

The kākāpō (Strigops habroptilus) is a critically endangered, flightless, nocturnal parrot endemic to New Zealand (Clout 2006; Powlesland et al. 2006) that has been the subject of one of the world's most intensive conservation management programmes (Clout 2006). Formerly widespread and abundant on the three main islands of New Zealand (Cresswell 1996; Miller et al. 2003), the kākāpō substantially declined following the introduction of mammalian predators (Lloyd \& Powlesland 1994). Intensive conservation has slowly increased the population from 51 individuals in 1995 (Elliott et al. 2001) to 154 individuals in 2017 . The 2017 population is confined to the small, predator-free island refuges of Whenua Hou (Codfish Island), Anchor Island, Pearl Island and Hauturu-o-toi (Little Barrier Island or Hauturu) (Fig 1).

Scientific research has been an integral component of kākāpō management and has aided in our understanding of their breeding biology, ecology, genetics and management requirements (Clout 2006). Translocations have been a key recovery tool, and until recently were limited to small islands off the southern end of New Zealand (Eason et al. 2006; Lloyd \& Powlesland 1994). These islands have similar environmental conditions, meaning that management between them has been relatively consistent. However, with an increasing kākāpō population, these small islands are nearing carrying capacity, and new, secure refuges for kākāpō are needed.

An important element of kākāpō conservation has been the recognition of a causal relationship between the onset of breeding and the phenology of key food plants. In summary, kākāpō breeding is significantly influenced by mast-seeding events, when plants produce abundant seed crops at irregular intervals (Silvertown 1980; Kelly 1994; Schauber et al. 2002; Kelly et al. 2013). South Island terrestrial ecosystems follow a strong mast-seeding pattern (Webb \& Kelly 1993; Schauber et al. 2002), and mast-seeding podocarp species, such as Dacrydium cupressinum (rimu), periodically provide abundant and nutritionally suitable food for female kākāpō to successfully raise young (Trewick 1996; Cottam et al. 2006; Harper et al. 2006). In contrast, North Island ecosystems have a warmer climate where a higher abundance of fleshy fruited species produce resources at more regular intervals ( $\mathrm{McNab}$ \& Salisbury 1995; Dijkgraaf 2002).

Kākāpō habitat selection in southern refuges differs across seasons and between breeding and non-breeding years, with a preference for habitat containing mast-seeding podocarp species during breeding years (Whitehead 2007; Joyce 2009). However, these species are uncommon (D. cupressinum) or absent (Lepidothamnus spp. and Halocarpus spp.) on Hauturu (Hamilton 1961).

Subfossil evidence in the North Island indicates that kākāpō once occupied a varied range of vegetation types prior to human arrival, including vegetation similar to that found on Hauturu (Moorhouse \& Powlesland 1991). While Hauturu itself has no historical evidence of kākāpō presence, it is a nationally significant predator-free refuge with high 


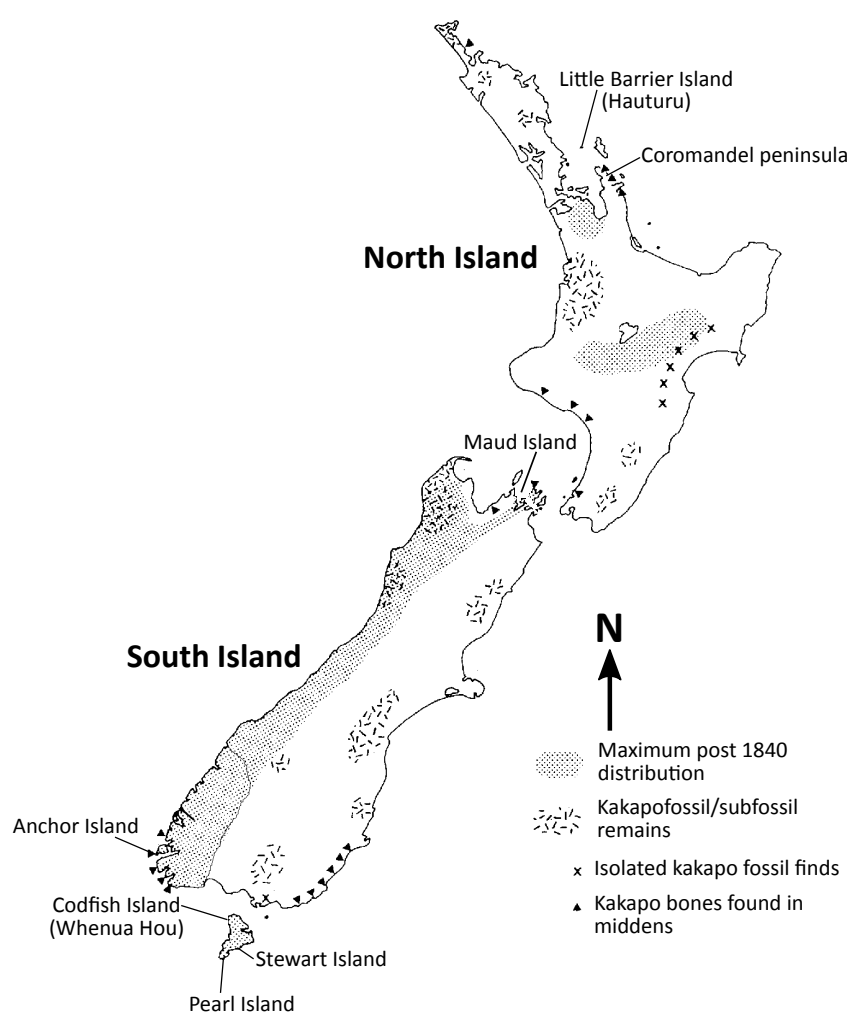

Figure 1. Past distribution of kākāpō and locations of current kākāpō offshore island refuges, modified from Miller et al (2003).

biodiversity, including other native parrots such as kākā (Nestor meridionalis) and kākāriki (Cyanoramphus spp.).

Translocation of kākāpō to Hauturu was first attempted in 1982, when 22 individuals were moved from Whenua Hou (Moorhouse \& Powlesland 1991). Despite the absence of known breeding triggers, multiple breeding attempts occurred during the 17 years (1982-1999) birds were present (Elliott et al. 2006). However, infertility and fledgling mortality from the predation of eggs and nestlings by the Polynesian rat, or kiore (Rattus exulans), meant that most of these attempts were unsuccessful (Harper 1995; Elliott et al. 2006). This failure, along with difficulties of managing kākāpō on Hauturu's rugged terrain led to their removal in 1999 (Eason et al. 2006).

Differences between the vegetation of southern and northern kākāpō refuges may have a significant influence on kākāpō breeding frequency and success. Successful eradication of cats in 1981 and kiore in 2004 means that Hauturu is now one of the few island refuges that is free of, and beyond the swimming range of, introduced predators. These attributes make it important to establish whether kākāpō could successfully breed on Hauturu. To answer this question, kākāpō were returned to Hauturu in April 2012. However, the fundamental question still remains unanswered: can kākāpō from southern New Zealand adapt to the different plant foods and phenological patterns of northern refuges such as Hauturu?

Our overall goal was to investigate habitat selection and breeding by kākāpō on Hauturu between 1991 and 1995 . Our specific aims were to: (1) analyse habitat preferences of breeding kākāpō during the 1995 breeding year; and (2) associate breeding and habitat preferences with phenological patterns recorded during this period. We show that habitat selection and breeding attempts may be linked to the phenology of specific species. The Hauturu phenology dataset also allows the analysis of phenology patterns in a range of northern coastal forest species that are often neglected in phenological research in New Zealand (Dijkgraaf 2002).

\section{Methods}

This paper presents an analysis of unpublished data on kākāpō spatial distribution and plant phenology on Hauturu that was collected by the kākāpō recovery team from 1991 to 1995.

\section{Kākāpō spatial data}

Data were obtained from the kākāpō recovery team, consisting of 1021 location points collected through radio triangulation by rangers during the 1994/95 breeding season for 16 individuals, 10 male $(n=613)$ and six female $(n=403)$. Locations were classified by gender and 1995 female breeding status so habitat selection by breeding $(n=199)$ and non-breeding $(n=209)$ females could be compared.

\section{Plant phenology data}

An unanalysed plant phenology dataset that was gathered in the 1990s was obtained from the kākāpo recovery team. The dataset included phenological observations of more than 70 plant species along two central tracks, for every month (except for 6 separate months due to weather or access issues) from 1991-1995. Phenology observations consisted of scores (0-3) for leaf buds, new growth, flower buds, flowers, green fruit and ripe fruit, where $0=$ absent and $3=$ abundant. For gymnosperms, female cones were counted as fruit. Monitored tracks were centrally located and included most of the main vegetation types present on the island. Individual plants were monitored along the entire elevation range, with subsamples collected at lower (0-250 m asl), middle (250-500 m asl) and upper ( $>500 \mathrm{~m}$ asl) elevation bands. Stone (2013) provides a detailed description of the data collection process. Both tracks were on the southern side of Hauturu, however, plant phenology is known to differ slightly between the northern and southern sides of the island. Fortunately, during the 1994/95 season kākāpō mainly occupied the southern side of Hauturu, so we can be relatively confident that phenology patterns recorded were occurring within kākāpō home ranges.

Plant nomenclature used throughout this paper follows the New Zealand Plant Conservation Network convention (www. nzpcn.org.nz) as of February 2017.

\section{Data analysis}

Kākāpō locations were imported intoArcView GIS(Version 10.1, Geographical Information Systems, ESRI Inc., Redlands, CA, USA). A digital elevation model (DEM) was sourced from the New Zealand Map 260 Series (Land Information New Zealand, Wellington, 1978) and was used to calculate elevation (with an error of $\pm 21.6 \mathrm{~m}$ ) for each individual kākāpō location on Hauturu. A digital copy of a vegetation map (scale 1:15 840) compiled by Hamilton (1961) was used to assess resource selection in relation to vegetation types present on Hauturu (Fig. 2).

Hamilton (1961) classified Hauturu's vegetation into 18 vegetation types. Of these, some, such as pasture and exposed cliff, were excluded from analysis as they were not visited or were inaccessible to kākāpō. This left 15 vegetation types (grouped by species similarity) that could be potentially selected by kākāpō (Table 1). 
Table 1. Vegetation types available to kākāpō on Hauturu. Vegetation types are grouped by dominant vegetation characteristics.

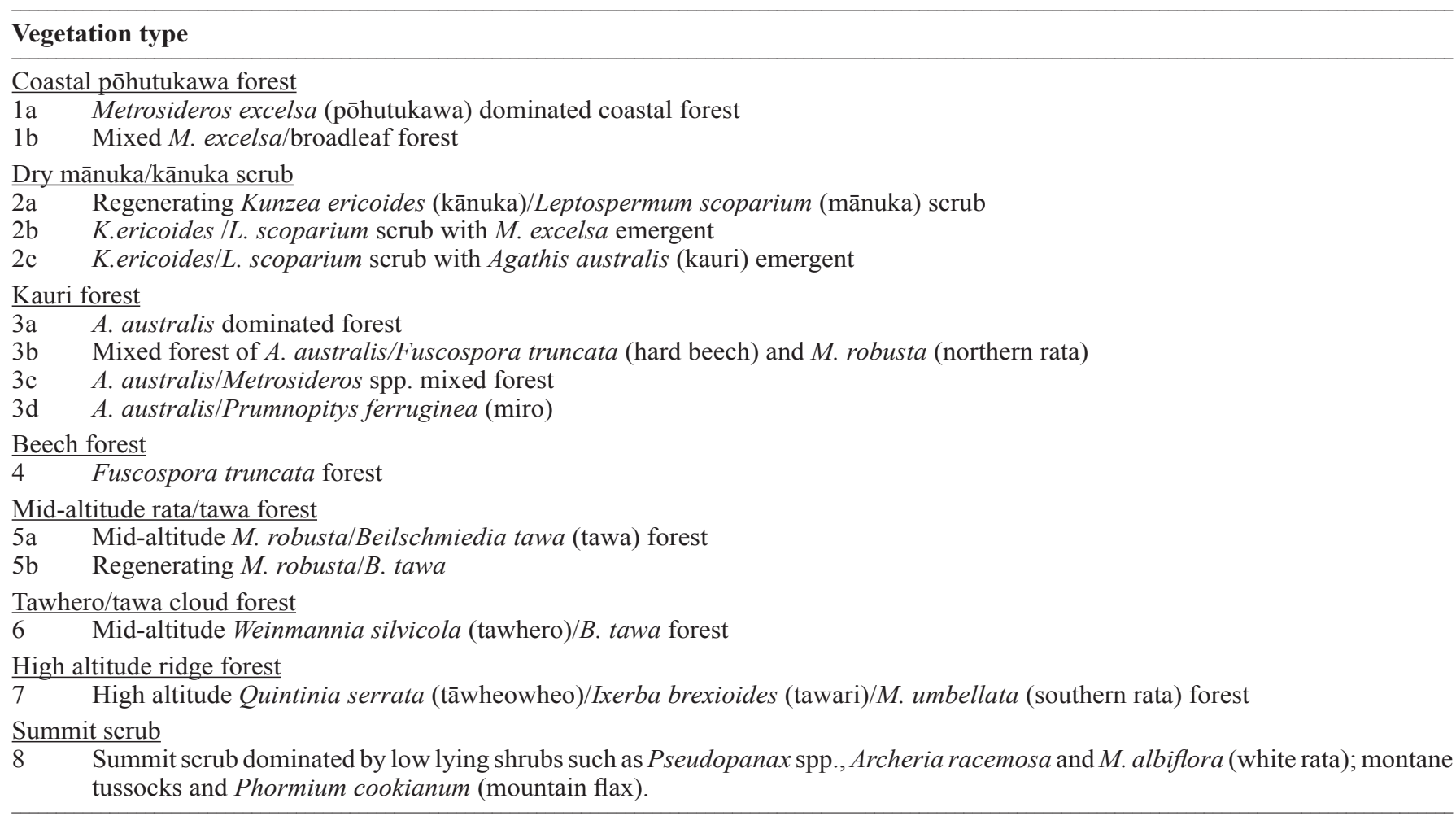

\section{Resource selection}

Individual and population resource selection and habitat preferences were estimated for each vegetation type based on kākāpō locations on Hauturu. Habitat preferences were determined by calculating resource selection ratios, which accommodated repeated observations of individuals (Manly et al. 1993, 2002). For this, the 1021 individual kākāpō location points were defined as 'used resource points'. Each used resource point was classified according to bird ID, gender and breeding status. Circular buffers of $25 \mathrm{~m}$ radius were generated around each point, to account for average telemetry error (calculated as $21.6 \mathrm{~m}$; Joyce 2008). In addition, a further buffer of $50 \mathrm{~m}$ was added onto each use resource point to account for average foraging movement between consecutive nights, and therefore total potential used resources for each point (Joyce 2008).

To measure habitat availability across Hauturu, a grid of potential resource points available to kākāpō was generated over the entire island. Available resource points were generated at $20 \mathrm{~m}$ intervals following the same procedure as used by Joyce (2008). This grid resulted in a total 76776 available resource points across Hauturu that were overlaid with the used resource points and buffers from kākāpō locations. Resource selection ratios could then be calculated by comparing the proportion of used and available resource points for kākāpō within each vegetation type.

Elevation is an important variable that is correlated with vegetation type on Hauturu, so an analysis of variance (ANOVA) was used to determine whether differences in kākāpō distribution were a result of altitude, rather than vegetation preferences. For this, log-linear models were used to determine whether distribution was influenced by gender, individual bird or breeding status (females only) based on used resource point buffers that accounted for both telemetry and altitude errors.
Individual resource selection was assessed by estimating the ratio of used resources to the available resources (Manly et al. 2002). To do so, the selection ratio for the $j$-th kākāpō and the $i$-th resource type (vegetation type) was determined by the ratio of the observed proportion of the $i$-th resource used by the $j$-th individual, compared to the known proportion of the $i$ type resource available to the population (Manly et al. 2002). After computing individual resource selection ratios for each individual, population resource selection ratios $(\hat{\mathrm{W}} i)$ for each gender/ breeding status subset in a given vegetation type were estimated using the methods described in Manly et al. (2002). The population selection ratio was determined by the proportion of type $i$ resources used by all individuals in the population compared to all known resources utilised by all individuals, divided by all $i$ resource units available.

Resource selection ratios were compared between breeding and non-breeding females during the 1995 season to test whether reproductive status influenced habitat selection. Moorhouse (1985) found little inter-annual variation in home ranges of kākāpō once established on Hauturu. Under the assumption that kākāpō home ranges did not vary greatly over the 5 years, and confirmation following the 2012 release of experienced birds returning to the same home range, location data collected from the 1995 season were also applied to 1993 breeding females.

Once resource selection and habitat preferences by kākāpō were calculated, the relationship between breeding success and fruiting phenology of plant species found in preferred vegetation types could be assessed. Phenology patterns of dominant plant species found in preferred vegetation types were assessed in terms of fruiting amplitude, or female cone amplitude in the case of gymnosperms, during kākāpō breeding years. A complete inventory of phenology patterns for all $70+$ plant species is provided in Stone (2013). 


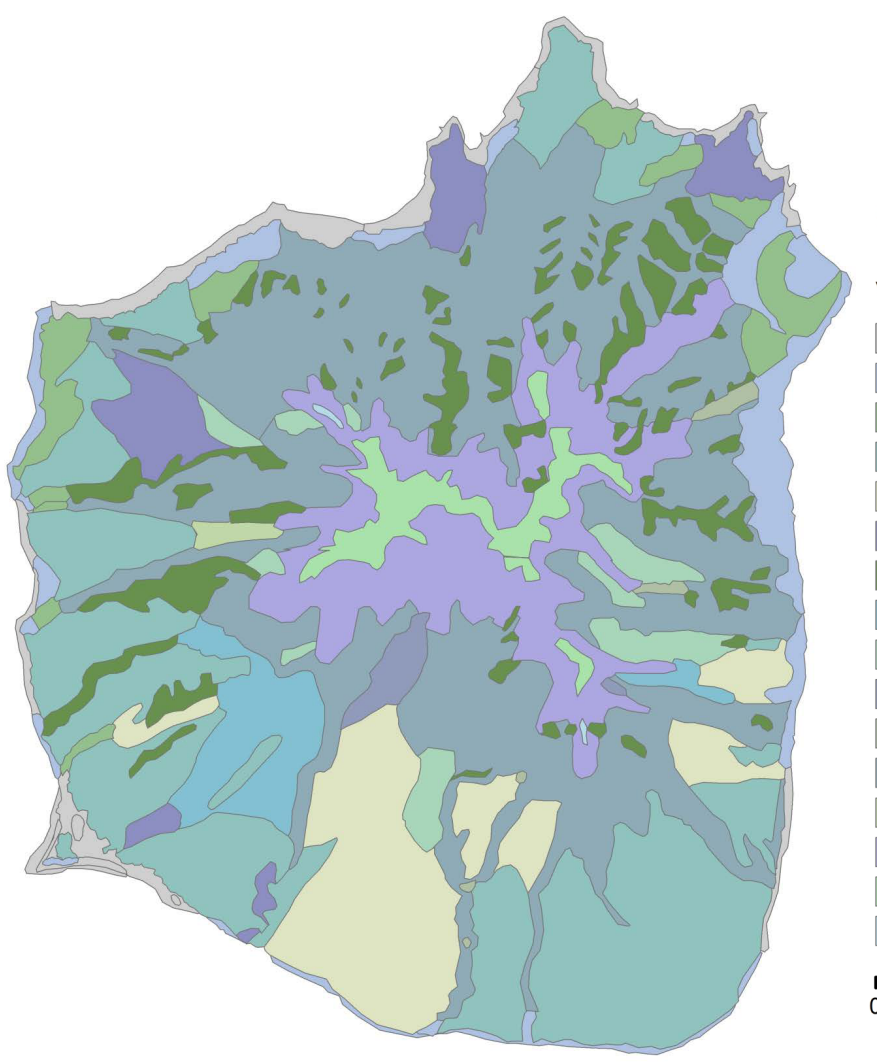

$\widehat{N}$

Vegetation types

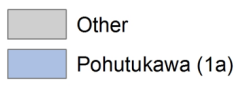

Pohutukawa/broadleaf (1b)

Kanuka/manuka (2a)

Kanuka/manuka/kauri emergent (2b)

Kanuka/manuka/pohutukawa emergent (2c)

Kauri (3a)

Kauri/beech/rata (3b)

Kauri/rata (3c)

Kauri/miro (3d)

Beech (4)

Rata/tawa (5a)

Regenerating rata/tawa (5b)

Tawhero/tawa (6)

Quintina/lxerba/southern rata (7)

LBI Summit Shrub (8)

$\begin{array}{lllll} & 0.25 & 0.5 & 1 & 1.5\end{array}$

Figure 2. Modified Hamilton (1961) vegetation classification map of Hauturu. Refer to Table 1 and Hamilton (1961) for complete vegetation map and species descriptions.

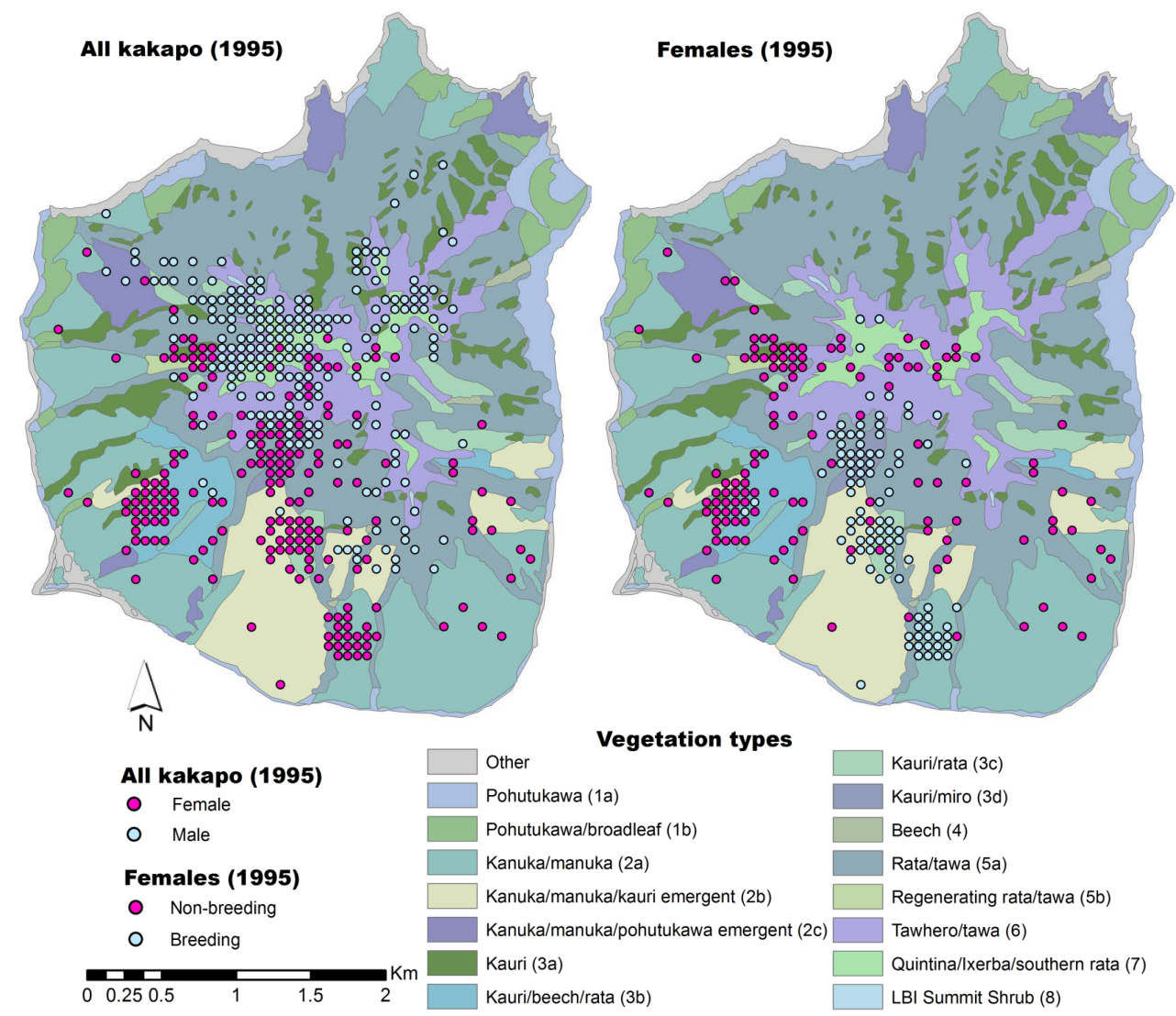

Figure 3. Locations of all kākāpō (left) and breeding and non-breeding females (right) during 1995 on Hauturu in relation to forest type. Refer to Table 1 and Hamilton (1961) for complete complete vegetation type and species descriptions. 
Results

\section{Kākāpō habitat selection and breeding status}

On their southern refuges, kākāpō habitat selection is strongly associated with individual characteristics. We found that this was also the case on Hauturu, with distinct differences in habitat selection found between individual, year, kākāpō sex and breeding status.

At the population level, kākāpō showed some preference for vegetation type $3 \mathrm{~d}$ (kauri/miro forest) with the highest resource selection ratio of $4.703(n=16)$ (Table 2). Vegetation types $1 \mathrm{a}$ and $1 \mathrm{~b}$ (coastal pōhutukawa-dominated communities) had the lowest resource selection ratios $(0.015$ and 0.082 , respectively). Of all the kākāpō groups for which selection ratios were calculated, the population preference for vegetation type $3 \mathrm{~d}$ was lower than selection ratios calculated by kākāpō demography.

Male and female kākāpō home ranges differed in elevation; male kākāpō tended to live at higher elevations than females (ANOVA F $=1037, \mathrm{DF}=1, \mathrm{P}<0.001$ ), often occupying the main peaks of the island (Fig. 3). When only female kākāpō were considered, a significant relationship was found between individual female home ranges and altitude (ANOVA $\mathrm{F}=$ 80.3, $\mathrm{DF}=5, \mathrm{P}<0.001$ ), although this did not significantly affect breeding status in 1995 (ANOVA $\mathrm{F}=0.312, \mathrm{DF}=1$, $\mathrm{P}=0.577$ ). This pattern suggests that breeding activity of female kākāpō on Hauturu was not linked to altitudinal factors alone.

Sex was a stronger influence on habitat selection than population; the highest population selection ratio was 4.703 whereas the highest sexual preferences were $>6$. This suggests that individual habitat selection was strongly associated with gender. Male kākāpō on Hauturu were found to preferentially select vegetation types 7 (high altitude ridge forest) and $3 \mathrm{~d}$ (kauri/miro forest) over all other vegetation types. In contrast, female kākāpō preferentially selected vegetation types $3 \mathrm{~d}$ (kauri/miro forest), $5 \mathrm{~b}$ (regenerating rata/tawa forest) and 6 (tawhero/tawa cloud forest) (Table 2).

The results of this analysis rely on a small sample size ( $n$ = six female kākāpō), which is often the case with critically endangered species conservation. As a result, care must be taken in the interpretation of data. Resource selection varied strongly between breeding and non-breeding females during the 1995 breeding season. While habitat selection was strongly based on sex, breeding status of female kākāpō provided the strongest selection ratios for vegetation type. Altogether, the three females that attempted to breed had a strong preference for vegetation type $3 \mathrm{~d}$, with the highest habitat selection ratio of 15.745 . Non-breeding females were found to select a wider range of vegetation types with lower selection ratios. Of the habitat selected, vegetation types $3 \mathrm{~b}$ (mixed kauri/beech/rata forest) and $5 \mathrm{~b}$ (regenerating rata/tawa forest) had the highest preference.

\section{Plant phenology}

Phenology data on Hauturu were collected from July 1991 to December 1995. During this period, female kākāpō attempted breeding in 1993 and 1995.

Overall, a higher abundance of reproductive phenophases (flowers and fruit/cones) of all species was recorded during the 1992/93 season than in the other seasons, suggesting a

Table 2. Population resource selection ratios ( $\hat{W} i$; Manley et al. 1993, 2002) for kākāpō during 1995 for vegetation types on Hauturu. A resource selection ratio $>1$ indicates a selection preference for that vegetation type (bold figures), while a value $<1$ indicates relative avoidance.

\begin{tabular}{|c|c|c|c|c|c|c|c|}
\hline \multicolumn{8}{|c|}{ Population resource selection ratio ( $\hat{\mathbf{W}} i)$} \\
\hline $\begin{array}{l}\text { Veg } \\
\text { ID }\end{array}$ & Vegetation type & $\begin{array}{l}\text { Total area } \\
\text { (ha) }\end{array}$ & $\begin{array}{c}\text { All } \\
\text { kākāpōo } \\
(n=16)\end{array}$ & $\begin{array}{c}\text { Males } \\
(n=10)\end{array}$ & $\begin{array}{l}\text { Females } \\
(n=6)\end{array}$ & $\begin{array}{c}\text { Non-breeding } \\
\text { females } \\
(n=3)\end{array}$ & $\begin{array}{c}\text { Breeding } \\
\text { females } \\
(n=3)\end{array}$ \\
\hline 1a & Metrosideros excelsa (pōhutukawa) & 143.02 & 0.015 & 0 & 0.027 & 0 & 0.06 \\
\hline $1 b$ & Mixed $M$. excelsa/broadleaf & 98.68 & 0.082 & 0 & 0.147 & 0.224 & 0 \\
\hline $2 \mathrm{a}$ & $\begin{array}{l}\text { Regenerating Kunzea ericoides } \\
\text { (kānuka)/Leptospermum scoparium } \\
\text { (mānuka) }\end{array}$ & 637.46 & 0.563 & 0.055 & 0.965 & 1.08 & 0.651 \\
\hline $2 b$ & $\begin{array}{l}\text { K.ericoides/L. scoparium scrub with } \\
\text { M. excelsa emergent }\end{array}$ & 102.99 & 0.698 & 0.835 & 0.565 & 0.859 & 0 \\
\hline $2 \mathrm{c}$ & $\begin{array}{l}\text { K.ericoides/L. scoparium scrub with } \\
\text { Agathis australis (kauri) emergent }\end{array}$ & 269.89 & 1.153 & 0.499 & 1.79 & 1.042 & 3.19 \\
\hline $3 \mathrm{a}$ & A. australis & 194.84 & 0.425 & 0.56 & 0.229 & 0.312 & 0.066 \\
\hline $3 b$ & $\begin{array}{l}\text { Mixed forest of } A \text {. australis/Fuscospora } \\
\text { truncata (hard beech) and M. robusta } \\
\text { (northern rata) }\end{array}$ & 93.23 & 1.684 & 0.393 & 2.669 & 4.204 & 0.766 \\
\hline $3 \mathrm{c}$ & A. australis/Metrosideros spp. & 73.75 & 1.792 & 1.108 & 2.154 & 1.261 & 3.862 \\
\hline $3 \mathrm{~d}$ & $\begin{array}{l}\text { A. australis/Prumnopitys ferruginea } \\
\text { (miro) }\end{array}$ & 21.21 & 4.703 & 6.233 & 6.732 & 3.175 & 15.745 \\
\hline 4 & Fuscospora truncata & 9.49 & 0.178 & 0 & 0.32 & 0.182 & 0.628 \\
\hline $5 \mathrm{a}$ & $\begin{array}{l}\text { Mid-altitude } M . \text { robusta/Beilschmiedia } \\
\text { tawa (tawa) }\end{array}$ & 935.13 & 0.924 & 0.994 & 0.809 & 0.726 & 0.9 \\
\hline $5 b$ & Regenerating $M$. robusta/B. tawa & 8.58 & 3.19 & 1.436 & 5.743 & 8.727 & 0 \\
\hline 6 & $\begin{array}{l}\text { Mid-altitude Weinmannia silvicola } \\
\text { (tawhero)/B. tawa }\end{array}$ & 312.3 & 2.148 & 3.323 & 1.124 & 1.543 & 0.407 \\
\hline 7 & $\begin{array}{l}\text { High altitude Quintinia serrata } \\
\text { (tāwheowheo)/Ixerba brexioides } \\
\text { (tawari)/M. umbellata (southern rata) }\end{array}$ & 73.68 & 3.838 & 6.473 & 1.901 & 1.897 & 1.464 \\
\hline
\end{tabular}


greater abundance of overall food resource in this season. Fruit and cones were more abundant during the 1993 season when breeding was attempted (Fig. 4). The abundance of reproductive plant phenophases in the 1994/95 breeding season was lower than in 1992/93 but higher than in the 1991/92 and 1993/94 seasons. During the 1992/93 season, the number of species fruiting/producing cones in relation to the total phenological score was relatively even (1:1 ratio) (Fig. 4). In contrast, the $1994 / 95$ season had a higher total phenological output in relation to the number of plant species fruiting/producing cones. This result suggests a higher individual species phenophase output, which is more consistent with masting.

If kākāpō breeding biology on Hauturu is consistent with that of their southern counterparts, we would expect a relationship between breeding years and high amplitude fruiting or cone production of particular plant species. Individual species phenology patterns showed only 13 species to have produced high amplitude fruit/cone crops during either the 1993 or 1995 breeding seasons (Table 3).

Of these species, only five, A. australis, Ixerba brexioides, Pittosporum umbellatum, Leptecophylla juniperina (mingimingi) and Rhopalostylis sapida (nikau), produced abundant fruit or cones during both years (Fig. 5). All five species produce either fruit or cones (female cones in the case of $A$. australis) during late summer/autumn, which corresponds with the general kākāpō chick-rearing period in their southern refugia. However, the timing of fruit ripening in $R$. sapida was less consistent, and ripe fruit were present on plants from May-September and April-June in 1993 and 1995 respectively (Fig. 5). A complete analysis of the phenological patterns of all plant species monitored is given in Stone (2013).

Some species produced abundant green fruit crops but had low ripening rates, potentially from high occurrence of seed predation by native and exotic species. Phormium cookianum produced abundant green fruit in both 1993 and 1995, but no ripe fruit were recorded. Freycinetia banksia (kiekie) also produced abundant green fruit during 1995, but no ripe fruit were recorded for this species either.

\section{Discussion}

Overall, our results suggest that male kākāpō selected higher elevation scrub vegetation while females preferentially selected mixed broadleaf and A. australis (kauri) forest. Breeding females showed a strong preference for kauri forest. The only chick successfully reared on Hauturu, a male, was fledged in A. australis forest. Phenology patterns showed that $A$. australis cone masting occurred during breeding years (1993 and 1995) and a higher overall phenological output occurred during 1993.

\section{Habitat selection and breeding in the absence of key podocarps}

Despite concerns to the contrary, kākāpō did attempt to breed during 5 of the 17 years they were on Hauturu (Elliott et al. 2006). From 1991-1995, breeding was attempted in 1991, 1993 and 1995, with 1991 the only year in which a chick successfully fledged. During 1995, female kākāpō, particularly breeding females $(n=3)$, were associated with vegetation dominated by $A$. australis, such as kauri/miro (type $3 \mathrm{~d}$ ) and kauri/northern rata (type 3c).

Before discussing A. australis and other non-podocarp species as possible breeding triggers, it is worth considering a podocarp present on Hauturu, Podocarpus. ferruginea. While relatively abundant at higher elevations, there was no association between $P$. ferruginea fruit production and kākāpō breeding. This pattern is consistent with observations on southern refuges, where $P$. ferruginea is consumed more during winter and is not essential to kākāpō breeding success (Powlesland et al. 1992). Therefore, it seems likely that non-podocarp species triggered kākāpō breeding on Hauturu (Powlesland et al. 1992; Clout \& Merton 1998; Cockrem 2002, 2006; Elliott et al. 2006; Harper et al. 2006).

Trewick (1996) discovered A. australis leaf cuticle in the faecal material of kākāpō chicks that were reared on Hauturu and speculated that $A$. australis may have triggered kākāpō breeding between 1982 and 1999. The apparent preference for $A$. australis dominated vegetation by breeding females shown here supports this hypothesis, and suggests that $A$. australis dominated vegetation provides important resources for nesting female kākāpō.

Further evidence for the potential of $A$. australis cones to trigger breeding in kākāpō is the nutritional similarities between A. australis and D. cupressinum. Agathis australis, Pinus radiata, and $D$. cupressinum cones are all high in terpenes, and $P$. radiata cones were preferentially selected by nesting females on Maud Island (Elliott et al. 2006; Walsh et al. 2006). This and other nutritional similarities may explain why $P$. radiata and $A$. australis cones are attractive to female kākāpō when D. cupressinum is absent (Walsh et al. 2006).

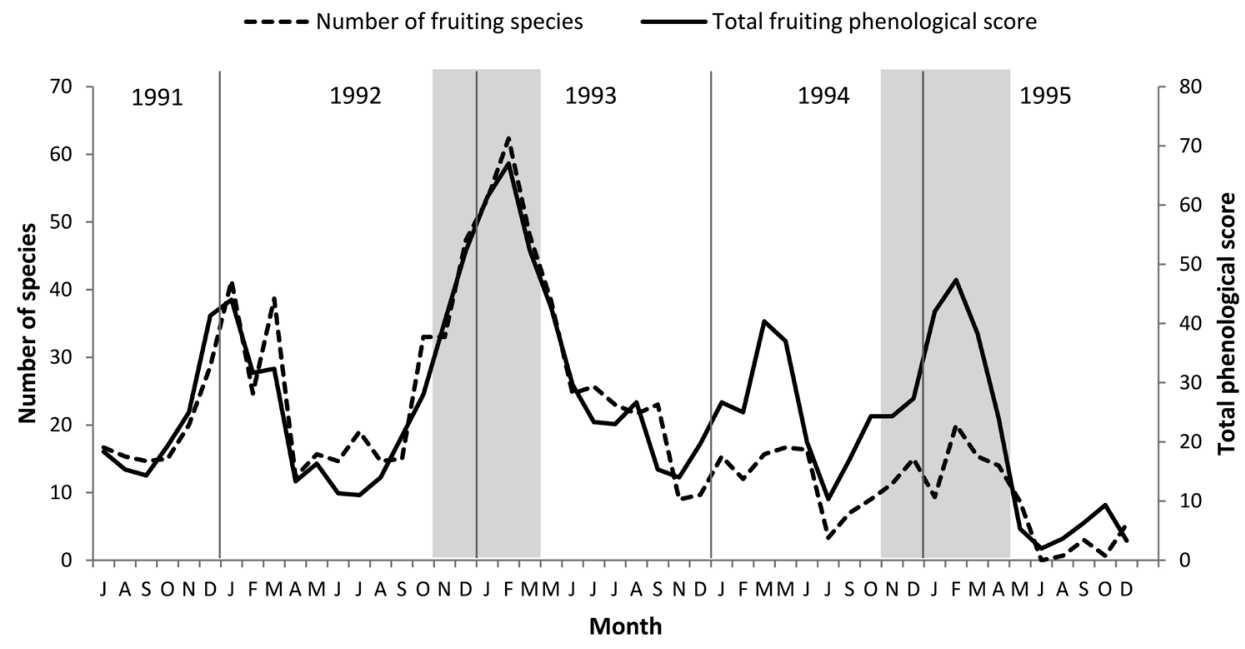

Figure 4. Total number of species fruiting (includes female cones for gymnosperm species) (dashed line) along the Thumb Track in relation to the total phenological score (solid line) given for each month from 1991-1995 on Hauturu. Shaded area represents months in which kākāpō breeding activity occurred. 

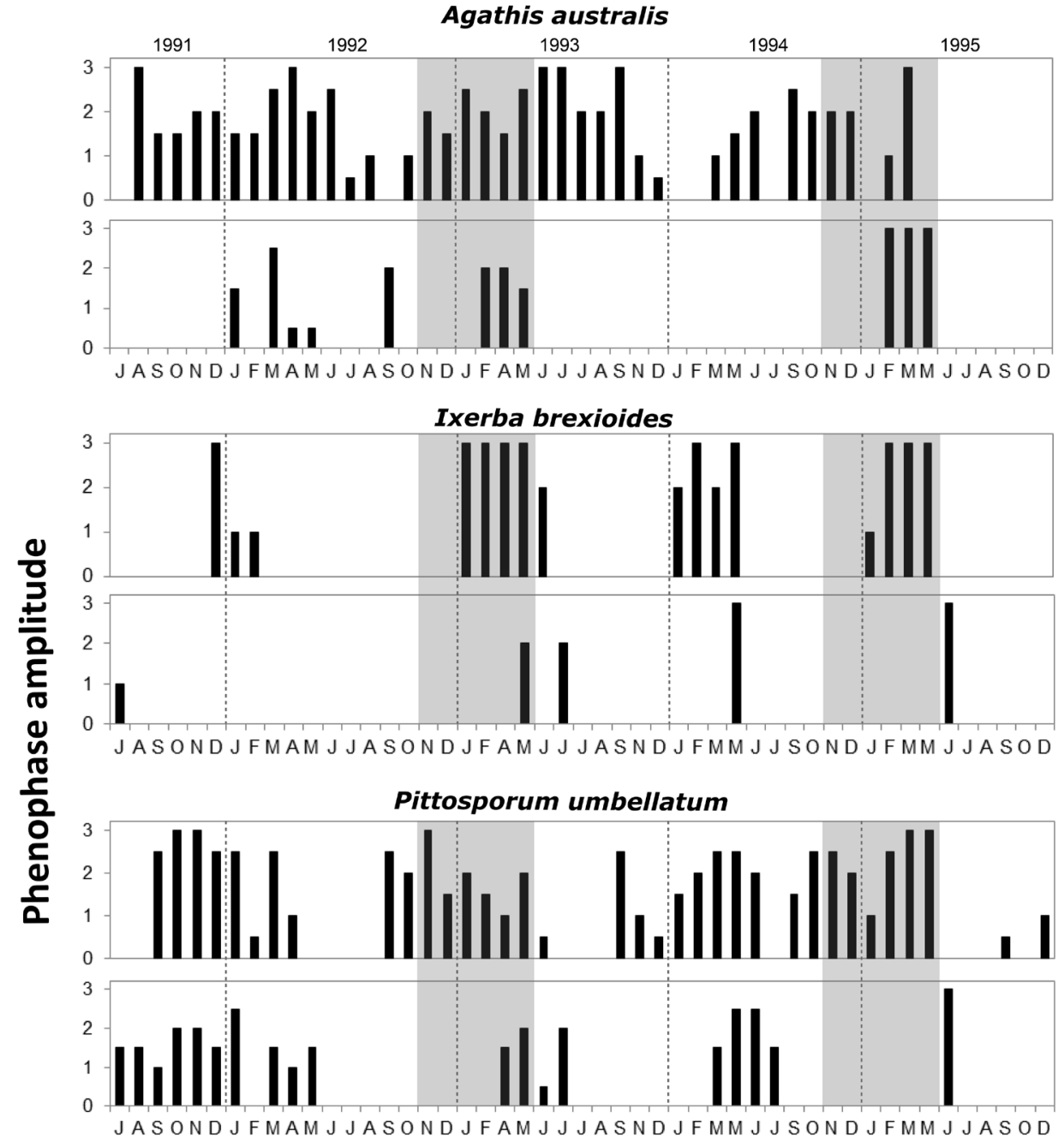

Rhopalostylis sapida

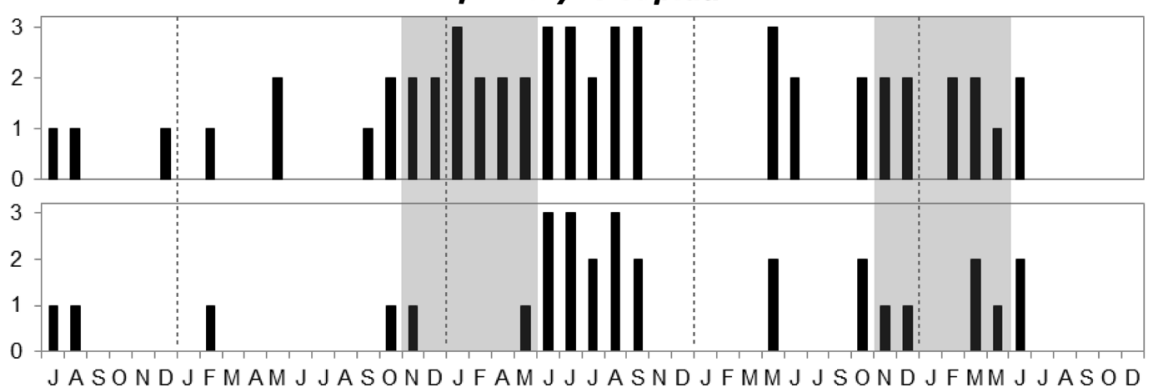

Month
Figure 5. Green (upper) and ripe (lower) fruit or female cone amplitudes for $A$. australis, $I$. brexioides, $P$. umbellatum and $R$. sapida on Hauturu from July 1991 until December 1995. Phenophase amplitude refers to the average score given for that species fruit or female cone abundance $(0=$ absent, $1=$ present, $2=$ common and $3=$ abundant). For A. australis, ripe cones are defined as mature female cones. Phenology data were collected at both the beginning and end of June 1993, while 6 months are data deficient due to bad weather or access issues. Shaded area represents months in which kākāpō breeding activity occurred.
Cone production by $A$. australis varies annually (Ecroyd 1982; Steward \& Beveridge 2010). On Hauturu, A. australis had an irregular annual reproductive pattern from 1991 to 1995. Although green female cones were produced in most years (Fig. 5), ripening was infrequent, peaking in 1995 (a breeding year). Unfortunately, phenology monitoring only began after ripe female cones would have been present in 1991, so we were unable to determine the abundance of ripe cones in this season. The only year when no ripe cones were observed was 1994, when no breeding was attempted. In addition, although kākāpō are skilled climbers (Best 1984), A. australis cones often break apart on the tree (Ecroyd 1982; Steward \& Beveridge 2010) and loose seed, or disintegrating cones, are abundant on the forest floor during late summer and autumn (ZLS, pers. obs.), which would make them easy for females to obtain. Intact female $A$. australis cones were also fed to a male kākāpō in 2012 at the Auckland Zoo; the cones were highly palatable and readily consumed by this bird (Daryl Eason, pers. comm.).

Araucariaceae seed has been shown to be an important breeding trigger for another parrot species, the Austral parakeet (Enicognathus ferrugineus), which breeds in response to mast seeding by Araucaria araucana at their northern range limit and Nothofagus pumilio at their southern limit (Díaz et al. 2012). Díaz et al. (2012) showed that northern populations fluctuate more than southern populations and attributed these 
Table 3. Plant species that produced abundant fruit or cone crops (phenophase amplitude of $\geq 2$ ) on Hauturu from $1991-1995$. $\circ$ (green fruit or cones) • (ripe fruit or cones).

\begin{tabular}{|c|c|c|c|c|c|}
\hline Species & 1991 & 1992 & 1993 & 1994 & 1995 \\
\hline \multicolumn{6}{|l|}{ Gymnosperms } \\
\hline Agathis australis & ○ & $\circ \bullet$ & $\circ \bullet$ & O & $\circ \bullet$ \\
\hline Podocarpus hallii & & $\circ$ & & & $\circ$ \\
\hline Prumnopitys ferruginea & & & ○ & & \\
\hline \multicolumn{6}{|l|}{ Dicots } \\
\hline Alseuosmia macrophylla & O & O & & O & \\
\hline Archeria racemosa & & ○ & $\circ \bullet$ & & ○ \\
\hline Beilschmiedia tarairi & $\bullet$ & & & & \\
\hline Beilschmiedia tawa & & & & $\circ$ & \\
\hline Brachyglottis kirkii & & $\bullet$ & $\bullet$ & & \\
\hline Coprosma grandifolia & & & & O & $\bullet$ \\
\hline Coprosma lucida & 0 & $\circ$ & ○ & ○ & ○ \\
\hline Coprosma rhamnoides & ○ & $\circ \bullet$ & ○ & $\circ \bullet$ & 0 \\
\hline Corokia buddleloides & ○ & ○ & & & ○ \\
\hline Dysoxylum spectabile & & & & O & $\circ \bullet$ \\
\hline Fuchsia excorticata & & O & & & \\
\hline Geniostoma ligustrifolium & O & ○ & 0 & O & $\circ$ \\
\hline Hebe spp. & $\circ$ & $\circ \bullet$ & $\circ \bullet$ & ○ & ○ \\
\hline Ixerba brexioides & ○ & & $\circ \bullet$ & $\circ \bullet$ & $\circ \bullet$ \\
\hline Knightia excelsa & O & ○ & ○ & & $\bullet$ \\
\hline Kunzea ericoides & & ○ & $\circ \bullet$ & & 0 \\
\hline Leptecophylla juniperina & $\circ \bullet$ & $\circ \bullet$ & $\circ \bullet$ & $\circ \bullet$ & $\circ \bullet$ \\
\hline Leucopogon fasciculatus & o & & & & \\
\hline Metrosideros albiflora & & ○ & ○ & $\circ \bullet$ & O \\
\hline Metrosideros fulgens & & & ○ & ○ & \\
\hline Metrosideros robusta & & $\circ \bullet$ & $\circ \bullet$ & $\bullet$ & \\
\hline Metrosideros umbellata & & & ○ & ○ & $\bullet$ \\
\hline Mida salicifolia & O & ○ & $\circ \bullet$ & O & \\
\hline Olearia furfuraceae & & & & & $\bullet$ \\
\hline Peraxilla tetrapetala & ○ & ○ & ○ & O & ○ \\
\hline Pittosporum tenuifolium & ० & ○ & $\circ \bullet$ & O & \\
\hline Pittosporum umbellatum & $\circ \bullet$ & $\circ \bullet$ & $\circ \bullet$ & $\circ \bullet$ & $\circ \bullet$ \\
\hline Pseudopanax arboreus & $\circ$ & $\circ \bullet$ & & & \\
\hline Pseudowintera axillaris & & ○ & 0 & O & \\
\hline Quintinia serrata & & $\circ \bullet$ & $\circ \bullet$ & $\circ \bullet$ & ○ \\
\hline Schefflera digitata & & & ○ & $\bullet$ & \\
\hline Weinmannia silvicola & & O & ○ & & \\
\hline \multicolumn{6}{|l|}{ Monocots } \\
\hline Astelia spp. & & & ○ & & \\
\hline Collospermum spp. & & & & & O \\
\hline Dianella nigra & & & O & & $\bullet$ \\
\hline Freycinetia banksii & & & & & $\circ \bullet$ \\
\hline Gahnia spp. & & $\circ \bullet$ & & & $\bullet$ \\
\hline Phormium cookianum & & ○ & ○ & & ○ \\
\hline Rhopalostylis sapida & & O & $\circ \bullet$ & $\circ \bullet$ & $\bullet$ \\
\hline
\end{tabular}

changes to the larger, but more variable, food resource provided by $A$. araucana. Araucaria araucana seed has a high starch content and is a vital food resource during breeding seasons (Henriquez et al. 2008). Therefore, Araucariaceae seed is an essential food source and trigger for breeding in at least one other parrot species. Like the Austral parakeet, kākāpō display different breeding frequencies in different habitats, presumably driven by differences in the phenology of local plant species.

A potentially confounding factor that needs to be considered is the provision of supplementary food on Hauturu and the extent to which it may have influenced kākāpō responses to natural triggers. However, it seems that supplementary food only allowed females to reach the required weight for breeding, rather than trigger breeding (Powlesland \& Lloyd 1994; Harper et al. 2006). Indeed, the reintroduction of kākāpō to Hauturu in 2012 was followed by breeding attempts in 2014, 2015 and 2016 , despite the fact that supplementary food was not provided to these birds. This demonstrates that the breeding of kākāpō on Hauturu is not triggered by supplementary food alone.

\section{Phenophase amplitudes and resource availability}

Female kākāpō attempted breeding in 2 of the 5 years between 1991 and 1995. These breeding seasons (1993 and 1995) had different phenology patterns, with overall higher phenophase amplitude in 1993, and a phenology pattern more typical of mast-seeding in 1995. Fruit and cone production on Hauturu during 1991/92 and 1992/93 had significantly higher amplitudes than during 1993/94 and 1994/95. The lowest observed flower and fruit/cone amplitude in 1991 and 1992 were similar to the peak flower and fruit/cone production observed in the 
following years. Despite the overall decrease in flowering in 1995 , female breeding activity was still recorded. This suggests that a potential breeding trigger may have been present during this season, despite the lower overall resource abundance. Although this trigger may have been sufficient to stimulate breeding activity, the lower overall resource abundance may have contributed to unsuccessful fledging.

If kākāpō breeding is triggered by a particular species on Hauturu, as in their southern refuges, the trigger species would be expected to have produced abundant fruit resources in both 1993 and 1995. A common species on Hauturu that does have a strong mast seeding pattern is hard beech (Fuscospora truncata). From 1991 to 1995, no mast event was observed on Hauturu for hard beech, therefore it is unlikely to have played a role in triggering kākāpō breeding.

A plant that did produce abundant seed crops during the 1993 and 1995 seasons was $A$. australis. Like D. cupressinum, female $A$. australis cones are present on trees for a lengthy period, with a reproductive cycle from pollination to seed maturation lasting up to 20 months (Owens et al. 1997). This cycle is an important feature as female kākāpō require sufficient time to anticipate seed crops to which they can raise young. Female cones are also abundant on the forest floor during autumn which, in contrast to D. cupressinum fruit, would allow kākāpō to forage without first climbing tall, emergent (c. $25 \mathrm{~m}$ ) trees. Future monitoring of A. australis phenology on Hauturu is recommended to determine whether it alone is triggering kākāpō breeding events, or whether it acts in conjunction with other plants.

Both $I$. brexioides and $R$. sapida also have relatively long reproductive cycles, with $I$. brexioides flower buds produced a year in advance, and remaining dormant until the following summer. The fruits of I. brexioides consist of black seeds with an incipient aril attached (Schneider 2007). These arils are rich in fatty oils (Schneider 2007) and may be similar in nutritional composition to $D$. cupressinum, which has a high protein, fatty acid and carbohydrate composition (Cottam et al. 2006). This species produced abundant fruit during both breeding years, but a lack of preference by females for the habitat in which it occurs (type 7) suggests it is not crucial for breeding, or had not yet been identified by females as a suitable food resource for breeding. Despite females not selecting I. brexioides dominated vegetation, I. brexioides is locally abundant within male home ranges. It is possible that it provides a high energy resource for male kākāpō during their energy intensive courtship displays and post-copulation recovery.

Rhopalostylis sapida is an important food source for other large New Zealand bird species, such as kererū (Hemiphaga novaeseelandiae). The fruit has a high lipid and calcium content, which is also a characteristic of $D$. cupressinum female cones (Dijkgraaf 2002; von Hurst et al. 2016). Rhopalostylis sapida is absent from southern kākāpō refuges, which has led to some speculation on its importance to breeding kākāpō. We found that from 1991-1995 R. sapida only produced abundant ripe fruit in the winter of 1993 (May-September). In other years, ripe fruit abundance was lower and was present on plants in spring and autumn. This suggests that while it may have been used by kākāpō, it was unlikely to trigger breeding activity. At present, kākāpō are not being provided with supplementary food on Hauturu. If this continues, the high lipid and calcium content of $R$. sapida fruit may become more important to newly reintroduced kākāpō than it was to birds that had access to supplementary food. Only one of the female kākāpō that did not receive supplementary food on Hauturu during the 1990s attempted to breed in 1993, which coincided with an abundant $R$. sapida fruiting crop.

Another species that produced an abundant fruit crop during a kākāpō breeding year was Freycinetia banksii (1995 only). Freycinetia banksii is found in a range of vegetation types on Hauturu, and is prominent in A. australis forest understorey (Hamilton 1961). It is also reported to produce fruit crops at irregular intervals. An early report by Austrian naturalist Andreas Reischek, translated by Westerskov (1981), stated that, in accordance with Māori legend, kākāpō breed in response to $F$. banksii fruiting. Although widespread throughout New Zealand, F. banksii is absent from Codfish and Anchor Islands. However, the vegetation of these island refuges is not necessarily representative of that in which kākāpō were historically found. In the absence of podocarps, northern kākāpō populations may respond to $F$. banksii.

Finally, Phormium cookianum (mountain flax) produces high quality seed that is a popular food resource for a range of native birds. However, only a low abundance of ripe fruit was observed on Hauturu. Naturally low seed maturation rates of $P$. cookianum on Hauturu could be attributed to high predation rates by kākāriki and other native seed predators (ZLS, pers. obs., 2011-2013). It is likely this was also the case in the 1990s, with decreased pollinator abundance and increased seed consumption by kiore also contributing (Craig 1989). Low abundance of ripe fruit of $F$. banksii may have also been due to its quick consumption by native species and kiore.

Successful hatching did occur in 1993, which could be attributed to the higher overall phenological amplitude observed. One particular breeding attempt in 1993 is noteworthy, as this female was not supplied with supplementary food. This individual was most strongly associated with regenerating pōhutukawa/tawa forest (type 5b), followed by kauri/miro (type $3 \mathrm{~d}$ ) and to a lesser extent the two higher altitude vegetation types (types 6 and 7). These vegetation types have relatively high combined species diversity, and many dominant plants produced high amplitude fruiting that year, including $A$. australis.

Although 4 and $1 / 2$ years is too short a period in which to accurately assess long term phenology patterns, the 1991-1995 dataset strongly suggests that pulses in plant resource abundance occur from year to year on Hauturu. These pulses are likely to be important ecosystem drivers, as plant phenophases provide the basic food resources required by many organisms for survival and reproduction. It appears that Hauturu resource pulses may result from two different overall phenology patterns occurring on Hauturu; general flowering years and mast seeding years.

\section{Conclusion}

Although the available kākāpō sample size on Hauturu at the time monitoring was undertaken $(n=22)$ was small, the results of this study provide some clues of possible kākāpō breeding triggers on Hauturu that conservation managers and subsequent researchers may wish to investigate further. Another, perhaps more valuable contribution of this paper, is to draw attention to the existence of an extensive plant phenology dataset that provides valuable insights on the dynamics of food resources provided by over 70 plant species through a number of growing seasons on Hauturu. A full set of graphs and explanatory notes for all these species is presented in Stone (2013). 
Although the potential for a sustainable population of kākāpō to become established on Hauturu is still uncertain, it is clear that triggers for breeding exist on the island. Preferential selection of $A$. australis dominated vegetation by breeding females and the relatively high nutritional value of plant species within this habitat suggests that this vegetation type may be important for breeding. Future analysis of $A$. australis cone nutritional composition may assist in understanding kākāpō nutritional requirements in northern ecosystems where $D$. cupressinum may be less abundant.

Although no historic evidence has been found of kākāpō on Hauturu, it was once part of the NZ mainland and it was likely to have kākāpō present(Hayward 1986; Moorhouse \& Powlesland 1991). In addition, kākāpō fossil evidence has been found on the Coromandel Peninsula and in the far north of the North Island, where $A$. australis is a prominent species (Newnham 1992; Miller et al. 2003). If breeding success on Codfish and Anchor Islands continues, additional island refuges will be required to accommodate the growing kākāpō population, but few offshore islands have appropriate vegetation to support breeding. Therefore, the secure refuge of Hauturu provides a critical opportunity to test the ability of kākāpō to establish a self-sustaining population in a floristically different habitat. If kākāpō are capable of successful recruitment there, without supplementary feeding, this will be a significant milestone in their conservation.

\section{Acknowledgements}

We firstly thank Ngāti Manuhiri, Ngāti Rehua and Ngāti Wai as the guardians of Hauturu-o-toi for permission and support of this study. We are grateful to the Department of Conservation and the Kākāpō Recovery Team without whose support this research would not have been possible. We thank Dr. Matt Rayner, Dr. James Russell, Dr. Leigh Joyce and Dr. Lesley Stone for their valuable advice and assistance, and the reviewers and editors of the New Zealand Journal of Ecology for their suggestions on improving this manuscript. Finally thank you to the Hauturu rangers: Shane McInnes, Liz Whitwell, Richard Walle, Leigh Joyce and Nichollete Brown for their assistance and hospitality throughout the project.

\section{References}

Best HA 1984. The foods of kākāpō on Stewart Island as determined from their feeding sign. New Zealand Journal of Ecology 7: 71-83.

Clout MN 2006. A celebration of kākāpō. Notornis 53: 1-2.

Clout MN, Merton D 1998. Saving the kākāpō: the conservation of the world's most peculiar parrot. Bird Conservation International 8: 281-296.

Cockrem JF 2002. Reproductive biology and conservation of the endangered kākāpō (Strigops habroptilus) in New Zealand. Avian and Poultry Biology Reviews 13: 139-144.

Cockrem JF 2006. The timing of breeding in the kākāpō (Strigops habroptilus). Notornis 53: 153-159.

Cottam Y, Merton DV, Hendriks W 2006. Nutrient composition of the diet of parent-raised kākāpō nestlings. Notornis 53: 90-99.

Craig JL 1989. Seed set in Phormium: interactive effects of pollinator behaviour, pollen carryover and pollen source. Oecologia 81: 1-5.
Cresswell MM 1996. Kākāpō recovery plan 1996-2005. Threatened species recovery plan No. 21. Wellington, Department of Conservation. $8 \mathrm{p}$.

Díaz S, Kitzberger T, Peris S 2012. Food resources and reproductive output of the austral parakeet (Enicognathus ferrugineus) in forests of northern Patagonia. Emu 112: 234-243.

Dijkgraaf AC 2002. Phenology and frugivory of large-fruited species in northern New Zealand and the impacts of introduced mammals. Unpublished PhD thesis, University of Auckland, New Zealand. 288 p.

Eason DK, Elliott GP, Merton DV, Jansen PW, Harper GA, Moorhouse RJ 2006. Breeding biology of kākāpō (Strigops habroptilus) on offshore island sanctuaries, 1990-2002. Notornis 53: 27-36.

Ecroyd CE 1982. Biological flora of New Zealand 8. Agathis australis (D. Don) Lindl. (Araucariaceae) kauri. New Zealand Journal of Botany 20: 17-36.

Elliott GP, Merton DV, Jansen PW 2001. Intensive management of a critically endangered species: the kākāpō. Biological Conservation 99: 121-133.

Elliott GP, Eason DK, Jansen PW, Merton DV, Harper GA, Moorhouse RJ 2006. Productivity of kākāpō (Strigops habroptilus) on offshore island refuges. Notornis 53: 138-142.

Hamilton WM 1961. Little Barrier Island(Hauturu). Wellington, Department of Industrial and Scientific Research. 198 p.

Harper GA 1995. Kākāpō on Little Barrier Island, annual report for the year July 1994-June 1995. Wellington, Department of Conservation. $43 \mathrm{p}$.

Harper GA, Elliott GP, Eason DK, Moorhouse RJ 2006. What triggers nesting of kākāpō (Strigops habroptilus)? Notornis 53: 160-163.

Hayward BW 1986. Origin of the offshore islands of northern New Zealand and their landform development. In: Wright AE, Beever RE eds. The offshore islands of northern New Zealand. Proceedings of a symposium convened by the Offshore Islands Research Group in Auckland, 10-13 May 1983. Information Series No. 16. Wellington, Department of Lands and Survey. Pp. 129-138.

Henriquez C, Escobar B, Figuerola F, Chiffelle I, Speisky H, Estevez AM 2008. Characterization of piñon seed (Araucaria araucana (Mol) K. Koch) and the isolated starch from the seed. Food Chemistry 107: 592-601.

Joyce L 2009. Movement patterns, home range and habitat selection by kākāpō (Strigops habrotilus, Gray 1845) following translocation to Pearl Island, Southern New Zealand. Unpublished PhD thesis, University of Otago, New Zealand. 333 p.

Kelly D 1994. The evolutionary ecology of mast seedling. Trends in Ecology and Evolution 9: 465-470.

Kelly D, Geldenhuis A, James A, HollandEP, Plank MJ, Brockie RE, Cowan PE, Harper GA, Lee WG, Maitland MJ, Mark AF, Mills JA, Wilson PR, Byrom AE 2013. Of mast and mean: differential-temperature cue makes mast seeding insensitive to climate change. Ecology Letters 16: 90-98.

Lloyd BD, Powlesland RG 1994. The decline of kākāpō Strigops habroptilus and attempts at conservation by translocation. Biological Conservation 69: 75-85.

McNab BK, Salisbury CA 1995. Energetics of New Zealand's temperate parrots. New Zealand Journal of Zoology 22: 339-349.

Manly BFJ, McDonald LL, Thomas DL 1993. Resource selection by animals: statistical design and analysis for 
field studies. London, Chapman and Hall. 177 p.

Manly BFJ, McDonald LL, Thomas DL, McDonald TL, Erickson WP 2002. Resource selection by animals: statistical design and analysis for field studies. 2nd edn. Dordrecht, Springer Netherlands. 222 p.

Miller HC, Lambert DM, Millar CD, Robertson BC, Minot EO 2003. Minisatellite DNA profiling detects lineages and parentage in the endangered kākāpō (Strigops habroptilus) despite low microsatellite DNA variation. Conservation Genetics 4: 265-274.

Moorhouse RJ 1985. Ecology of kākāpō(Strigops habroptilus) liberated on Little Barrier Island (Hauturu). Unpublished MSc thesis, University of Auckland, New Zealand. 151 p.

Moorhouse RJ, Powlesland RG 1991. Aspects of the ecology of kākāpō Strigops habroptilus liberated on Little Barrier Island (Hauturu), New Zealand. Biological Conservation 56: $349-365$.

Newnham RM 1992. A 30,000 year pollen, vegetation and climate record from Otakairangi (Hikrangi), Northland, New Zealand. Journal of Biogeography 19: 541-554.

Owens JN, Catalano GL, Aitken-Christie J 1997. The reproductive biology of kauri (Agathis australis). IV. Late embryogeny, histochemistry, cone and seed morphology. International Journal of Plant Sciences 158: 395-407.

Powlesland RG, Lloyd BD 1994. Use of supplementary feeding to induce breeding in free-living kākāpō Strigops habroptilus in New Zealand. Biological Conservation 69: 97-106.

Powlesland RG, Lloyd BD, Best HA, Merton DV 1992. Breeding biology of the kākāpō Strigops habroptilus on Stewart Island, New Zealand. Ibis 134: 361-373.

Powlesland RG, Merton DV, Cockrem JF 2006. A parrot apart: the natural history of the kākāpō (Strigops habroptilus), and the context of its conservation management. Notornis 53: $3-26$.

Editorial board member: David Pattemore

Received 15 February 2017; accepted 12 May 2017
Schauber EM, Kelly D, Turchin P, Simon C, Lee WG, Allen RB, Payton IJ, Wilson PR, Cowan PE, Brockie RE 2002. Masting by eighteen New Zealand plant species: the role of temperature as a synchronizing cue. Ecology 83: 1214-1225.

Schneider JV 2007. Ixerbaceae. In: Kubitzki K ed. Flowering plants. Eudicots. Heidelberg, Springer Berlin. Pp. 205-207.

Silvertown JW 1980. The evolutionary ecology of mast seeding in trees. Biological Journal of the Linnean Society 14: 235-250.

Steward GA, Beveridge AE 2010. A review of New Zealand kauri (Agathis australis (D. Don) Lindl.): its ecology, history, growth and potential for management for timber. New Zealand Journal of Forestry Science 40: 33-59.

Stone ZL 2013. Plant phenology of Hauturu (Little Barrier Island): variation in fruiting and flowering patterns and the implications for wildlife management, particularly kākāpō (Strigops habroptilus). Unpublished MSc thesis, University of Auckland, New Zealand. 245 p.

Trewick S 1996. The diet of kakapo (Strigops habroptilus), takahe (Porphyrio mantelli) and pukeko (P. porphyrio melanotus) studied by faecal analysis. Notornis 43: 79-84.

von Hurst PR, Moorhouse RJ, Raubenheimer D 2016. Preferred natural food of breeding kākāpō is a high value source of calcium and vitamin D. The Journal of Steroid Biochemistry and Molecular Biology 164: 177-179.

Walsh J, Wilson KJ, Elliott GP 2006. Seasonal changes in home range size and habitat selection by kākāpō (Strigops habroptilus) on Maud Island. Notornis 53: 143-149.

Webb CJ, Kelly D 1993. The reproductive biology of the New Zealand flora. Trends in Ecology and Evolution 8: 442-447.

Westerskov KE 1981. Reischek's 1890 paper on the kākāpō in the wild and in captivity. Notornis 28: 263-280.

Whitehead JK 2007. Breeding success of adult female kākāpō (Strigops habroptilus) on Codfish Island (Whenua Hou): correlations with foraging home ranges and habitat selection. Upublished MSc thesis, Lincoln University, New Zealand. 134 p. 